\title{
Research on the Influence of Equity Incentive to the Reliability of Accounting Information in Energy Industry Based on Panel Data of Fifty-one Listing Companies
}

\author{
Yongchen LI, Fang LI, Xiangbao DING \\ Department of Economic Management, North China Electric Power University, P. R. China. \\ workmbox_beryl@126.com
}

\begin{abstract}
In recent years, equity incentive have appeared some problems such as that earnings fail to offset incentive costs in its process of rapid development. Panel data from 2010 to 2014 of 48 listing enterprises in Chinese energy industry was chosen in this paper, and used to research the influence of equity incentive to the reliability of accounting information, which was based on earnings management and choice behavior theory. And the result tells that, when carrying out equity incentives, measures are taken by executives under the guidance of self-interested behavior, and this lowers the reliability levels of accounting information.

Index Terms - Equity incentives, Reliability of accounting information, control of earnings, Electric power enterprise
\end{abstract}

\section{Introduction}

A certain percentage of the company's equity is given to senior executives through equity incentives, which, in principle, can coordinate the conflicts of interests between the shareholders and the executives better. Since 2008, equity incentive have developed rapidly in China, but many failure cases have been emerged during this time, such as earnings can not compensate for incentive expenses (Haiyao, Yili). This may be due to the control of earnings of executives. ${ }^{[1]}$ So, to reveal its reasons further and test that whether equity incentive in China consistent with its original intention or not, this paper takes accounting information quality as the foothold. By processing the statistical data through SPSS17.0 and setting the equity incentive as the independent variables, the reliability level of accounting information as the dependent variable, influence of equity incentive on the quality of accounting information in the electric power industry are explored.

\section{Theoretical Analysis and Research Hypothesis}

In present studies, one point of view supports that the equity incentive plans of listing corporation make interest of shareholders and executives consistent by cutting down the principal-agent costs, and improve the quality of accounting information as a result; another view is that the equity incentive plans of listing corporation lead to control of earnings, and reduce the quality of accounting information. ${ }^{[2]}$

The author argue that, by establishing a certain degree of contact between the interest of executives and the long-term performance of company, the equity incentive plans urge executives, who are driven by self-interest, to maximize the value of company, and reduce the supervision costs of shareholders and agency costs. But only when all of these efforts reported in the financial report truthfully and comprehensively can executives be examined reasonably, and excitation works then. ${ }^{[3]}$ However, for the reason of taking the performance of company as assessment index, the more equity the executive takes, the more motivation of control of earnings they have, which makes the phenomenon of operating profit very universal in Chinese listing companies. If things going like this, it may going against long-term development of the company.

Based on this, the degree of control of earnings is chosen to measure the reliability level of accounting information in this paper, and the following hypothesis is suggested:

$\mathrm{H}$ : the higher the degree of equity incentive, the higher the degree of control of earnings, and the lower the reliability level of accounting information.

\section{Design of Research}

\section{A. Sample of Research}

This paper selects A shares listing corporations in Chinese energy industry, and chooses panel data from 2011 to 2013 of them. After eliminating samples of data missing or exception, 144 valid samples are reserved.

\section{B. Variable Selection and Source of Data 1) Dependent Variable}

Based on the theoretical analysis, the degree of control of earnings is chosen to measure the reliability level of accounting information in this paper, the higher the degree of control of earnings, and the lower the reliability level of accounting information. Considering previous studies on control of earnings, this paper chooses Modified Section Jones Model as the substitution variable of the reliability level of accounting information. And the concrete model is:

$$
\frac{T A_{i, t}}{A_{i, t-l}}=\alpha_{0} \times \frac{1}{A_{i, t-l}}+\alpha_{1} \times\left(\frac{\Delta R E V_{i, t}}{A_{i, t-l}}-\frac{\Delta R E C_{i, t}}{A_{i, t-1}}\right)+\alpha_{2} \times \frac{F A_{i, t}}{A_{i, t-l}}+\alpha_{3} \times \frac{I A_{i, t}}{A_{i, t-l}}+\varepsilon_{i, t}
$$


TABLEI Meaning of Modified Section Jones Model

\begin{tabular}{|c|l|}
\hline Var. & \multicolumn{1}{|c|}{ Meaning } \\
\hline$T A_{i, t}$ & Total accrued profit of $\mathrm{i}$ company in $\mathrm{t}$ years \\
\hline$A_{i, t}$ & Total assets of $\mathrm{i}$ company in t years \\
\hline$\Delta R E V_{i, t}$ & Operating income difference of $\mathrm{i}$ company of $\mathrm{t}$ and $\mathrm{t}-1$ years \\
\hline$\Delta R E C_{i, t}$ & Accounts receivable difference of $\mathrm{i}$ company of $\mathrm{t}$ and $\mathrm{t}-1$ years \\
\hline$F A_{i, t}$ & Book value of fixed assets of of $\mathrm{i}$ company in $\mathrm{t}$ years \\
\hline$I A_{i, t}$ & $\begin{array}{l}\text { Total of intangible assets and other non dynamic assets of } \mathrm{i} \\
\text { company in t years }\end{array}$ \\
\hline
\end{tabular}

Calculating the estimate value of $\alpha_{0}, \alpha_{1}, \alpha_{2}$ and $\alpha_{3}$, and calculating the degree of control of earnings $(Y)$ through formula (2) and (3), and used to measure the reliability level of accounting information.

$$
\begin{gathered}
\frac{D N A_{i, t}}{A_{i, t-l}}=\alpha_{0} \times \frac{1}{A_{i, t-l}}+\alpha_{1} \times\left(\frac{\Delta R E V_{i, t}}{A_{i, t-l}}-\frac{\Delta R E C_{i, t}}{A_{i, t-l}}\right)+\alpha_{2} \times \frac{F A_{i, t}}{A_{i, t-l}}+\alpha_{3} \times \frac{I A_{i, t}}{A_{i, t-l}} \\
Y=\left|\frac{D A_{i, t}}{A_{i, t-l}}\right|=\left|\frac{T A_{i, t}}{A_{i, t-l}}-\frac{N D A_{i, t}}{A_{i, t-l}}\right|
\end{gathered}
$$

\section{2) Independent Variable}

This paper takes shareholding ratio of executives $(S R E)$, which is accepted by most of studies, as the substitution variable of the equity incentive degree $(E)$.

\section{3) Control Variable}

Other variables, excepting independent variable, such as the size of company, profitability and organization structure, also affect the reliability level of accounting information. And the following control variables are selected:

TABLEII Definition of Control Variables

\begin{tabular}{|l|c|l|}
\hline \multicolumn{1}{|c|}{ Name of var. } & Symbol & \multicolumn{1}{c|}{ Meaning } \\
\hline The size of company & SIZE & Natural logarithm of total assets \\
\hline Financial leverage & $L E V$ & Assets liability ratio \\
\hline Company performance & $C F P$ & Weighted return on net assets \\
\hline $\begin{array}{l}\text { Independent director } \\
\text { ratio }\end{array}$ & $I D R$ & $\begin{array}{l}\text { The proportion of independent } \\
\text { directors in all }\end{array}$ \\
\hline $\begin{array}{l}\text { Whether the chairman is } \\
\text { the general manager }\end{array}$ & $C P$ & Take 1 if yes, take 0 if no \\
\hline Growth & GROW & Operating profit growth rate \\
\hline
\end{tabular}

The data used in this paper are from the database of CSMAR, and are accessed directly or after further processing.

\section{Method of Research}

Based on the descriptive statistics and correlation analysis of data in this section, step-wise regression is selected in the empirical research to analyse the influence of equity incentive to the reliability level of accounting information. Based on this, following decision model for the reliability level of accounting information is constructed:

$$
Y_{i, t}=\beta_{0}+\beta_{1} \times E_{i, t}+\sum_{l}^{6} \omega_{k} \times \text { Determinants }+\mu_{i, t}
$$

Determinants express the set of control variables selected into the model, and it will be optimized by step-wise regression below.

The statistics of tab. 3 shows the following characteristics: there is a wide difference between the maximum and minimum of both the degree of control of earnings and shareholding ratio of executives. Actually, there are $52 \%$ of companies whose executives holding shares in all of the samples, and it gives a mean of 0.0324 , which indicates that the degree of equity incentive is generally low. And so is the degree of control of earnings.

TABLEIII Descriptive Statistics of Variable

\begin{tabular}{|c|c|c|c|c|c|c|c|c|}
\hline Var & $Y$ & $E$ & SIZE & $L E V$ & $C F P$ & $I D R$ & $C P$ & $G R O$ \\
\hline$Y$ & 1 & & & & & & & \\
\hline$E$ & .227 & 1 & & & & & & \\
\hline SIZE & 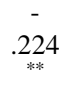 & $\begin{array}{c}- \\
.124\end{array}$ & 1 & & & & & \\
\hline$L E V$ & 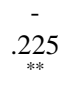 & $\begin{array}{c}- \\
.178 \\
*\end{array}$ & $\begin{array}{c}.366^{*} \\
*\end{array}$ & 1 & & & & \\
\hline$C F P$ & .153 & .082 & .096 & $\overline{-}^{-} 8^{* *}$ & 1 & & & \\
\hline$I D R$ & $\begin{array}{c}- \\
.089 \\
\end{array}$ & $\begin{array}{c}- \\
.040 \\
\end{array}$ & -.110 & -.022 & -.009 & 1 & & \\
\hline$C P$ & .013 & $\begin{array}{c}- \\
.019\end{array}$ & -.056 & .012 & .001 & .104 & 1 & \\
\hline GRO & .030 & $\begin{array}{c} \\
018\end{array}$ & .125 & .046 & $\begin{array}{c}376^{*} \\
*\end{array}$ & $\begin{array}{c}- \\
.205^{*}\end{array}$ & $\begin{array}{c}- \\
.022 \\
\end{array}$ & 1 \\
\hline
\end{tabular}

\begin{tabular}{|c|c|c|c|c|c|}
\hline Var. & $\mathrm{N}$ & Min. & Max. & Means & Stat. \\
\hline$Y$ & 144 & .0004 & .1496 & .0391 & .0318 \\
\hline$E$ & 144 & .0000 & .8870 & .0324 & .1399 \\
\hline SIZE & 144 & 11.2600 & 17.1600 & 14.0663 & 1.3791 \\
\hline LEV & 144 & .0100 & .9400 & .6350 & .1790 \\
\hline$C F P$ & 144 & -69.8100 & 33.7400 & 7.7679 & 10.7417 \\
\hline$I D R$ & 144 & .1400 & .5700 & .3668 & .0589 \\
\hline$C P$ & 144 & 0 & 1 & .01 & .0830 \\
\hline GRO & 144 & -5.9200 & 7.3900 & .5662 & 1.9158 \\
\hline
\end{tabular}

TABLEIV Pear son correlation coefficient

**.significant correlation at.01 levels (bilateral);

*.significant correlation at.01 levels (bilateral).

The statistics of tab. 4 shows the following characteristics: the severe multiple col-linearity problem is solved successfully with a absolute value of correlation coefficient of 0.4 of variables; the degree of control of earnings has a significant positive correlation with the shareholding ratio of executives at the level of 0.01, and with the size of companies and financial leverage also, while has not with others. 


\section{Empirical Analysis}

\section{A. Regression Analysis}

By filtering control variables with the principle of $p$-max and $t$-min of backward step-wise regression, the final regression model is obtained as follow:

$$
Y=\beta_{0}+\beta_{1} \times E+\omega_{1} \times S I Z E+\omega_{2} \times L E V+\omega_{3} \times C F P+\omega_{4} \times I D R+\omega_{5} \times C P+\sigma
$$

The statistics of tab.5 is given by OLS regression analysis:

TABLEV The regression results of the influence of stock option incentive on the reliability of accounting information

\begin{tabular}{|c|c|c|c|c|c|}
\hline \multirow{2}{*}{ Var. } & \multirow{2}{*}{$\mathrm{B}$} & $\mathrm{t}$ & \multirow{2}{*}{ Sig. } & \multicolumn{2}{|c|}{ Statistic of col-linearity } \\
\cline { 5 - 6 } & & & & Tole. & VIF \\
\hline $\mathrm{C}$ & .129 & 3.969 & .000 & .957 & 1.045 \\
\hline$E$ & .038 & 2.056 & .038 & .813 & 1.229 \\
\hline SIZE & -.004 & -2.009 & .042 & .772 & 1.296 \\
\hline$L E V$ & -.024 & -1.472 & .043 & .765 & 1.307 \\
\hline$C F P$ & .000 & 1.412 & .047 & .931 & 1.074 \\
\hline$I D R$ & -.058 & -1.298 & .147 & .985 & 1.015 \\
\hline$C P$ & .007 & .214 & .831 & .799 & 1.252 \\
\hline \multicolumn{7}{|l|}{$\mathrm{R}^{2}=0.103 ;$ Durbin-Watson=2.053; F-statistic=0.030 (.000) } \\
\hline
\end{tabular}

The results of regression shows the following information: with a significant positive correlation between the equity incentive $(E)$ and the degree of control of earnings $(Y)$ at the level of 5\%, it confirms that the executive equity incentive of listing companies can increase the behavior of control of earnings and let down the level of reliability of accounting information in the range of this paper, which matches to expectation hypothesis. Meanwhile, with the VIF (variance expansion factor) less than 10 and the mean of 1.174, multiple col-linearity among all of these variables can be avoided.

The regression results of control variables shows that there is a significant correlation between the company performance $(C F P)$ and the degree of control of earnings $(Y)$ while expressing a correlation coefficient of zero. This paper deems that, the company performance markedly related to the degree of control of earnings $(Y)$ for the reason of taking company performance $(C F P)$ to assess executives; but at the same time, the performance of company may be made low by executives before exercising but be promoted after that, which does influence on coefficients. In addition, independent director ratio $(I D R)$ and whether the chairman is the general manager $(C P)$ all have a not very notable correlation with the degree of control of earnings $(Y)$ at the level of 5\%, cases with these two features out of samples too exiguous may lead to this.

Other four optimization models are existent, and no matter which one, significant positive correlation still founded between the equity incentive $(E)$ and the degree of control of earnings $(Y)$ at the level of $5 \%$, which explains that the equity incentive systems of Chinese electric power industry actually stimulate the executives to choose control of earnings for their own interest further.
The results and analysis of the experiments proved the hypothesis of $\mathrm{H}$.

\section{B. Test of Robustness}

This paper takes the the ratio of the value of equity to their total remuneration of the executives $\left(E^{\prime}\right)$ as a new substitution variable of the degree of equity incentive to test the robustness of main model, and data used here is also from the 144 samples. Limited to the space, only result of test explained simply in this paper. the result shows that, $E$ ' has a similar descriptive statistics with $E$. But $E$ ' represents the interest of executives them-selves while $E$ appears from the overall perspective of the company. Result of regression is also similar, that is, the equity incentive promote the behavior of control of earnings in the view of the interests of executives themselves, and let down the reliability level of accounting information. The influence of equity incentive to the reliability of accounting information in power industry.

\section{Conclusion}

Research on the influence of equity incentive to the reliability of accounting information in power industry in the view of control of earnings confirms that, to maximize their own interests, executives choose to control earnings, which lower the reliability of accounting information. This paper indicates that the reliability of accounting information is lowered by equity incentive overall, even though the impact on it is miscellaneous. Based on this, following suggestions are put forward: improvement about equity incentive implementation plan should be taken, such as adjusting the assessment index, and discovering, summarizing and checking ceaselessly to enhance the affection of equity incentive.

For the finding of this paper just aim at Chinese power generation enterprises, and the data of the degree of equity incentive is generally low, the accuracy of conclusion may be impacted. Just as what Morck (1998) said that the affecting of equity incentive related to its degree: only when in the interval of 0 to $5 \%$ or above $25 \%$, do positive function works, and negative one otherwise. ${ }^{[5]}$ So, more data and methods should be taken for researching the influence of equity incentive to the reliability of accounting information of listing companies in Chinese electric power industry.

\section{References}

[1] Z. Nie. Theoretical foundation and its properties of stock ownership incentive. Modern Management Science. vol. 10, pp. 41- 42, 2008.

[2] A. Jiang. The study on the influence of stock incentive on the quality of accounting information of listing Corporation. Chengdu: Southwest Jiaotong University, pp. 9-14, 2010.

[3] Y. Shu, M. Zhang. Research on equity incentive in the perspective of executive action. Friends of Accounting. vol. 10, pp. 96-97, 2013.

[4] N. Gong, J. Sun. A summary of the relationship between equity incentives, opportunism and accounting information quality.Friends of Accounting.vol.5, pp. 63-65, 2015.

[5] R. Morck, A. Shleifer and R.W. Vishny. Managerial ownership and market valuation: An empirical analysis. Journal of Financial Economics, vol.20, pp. 192-315, 1998. 